\title{
Rac1 Mediates Collapsin-1-Induced Growth Cone Collapse
}

\author{
Zhao Jin and Stephen M. Strittmatter \\ Departments of Neurology and Neurobiology, Yale University School of Medicine, New Haven, Connecticut 06520
}

Collapsin-1 or semaphorin III(D) inhibits axonal outgrowth by collapsing the lamellipodial and filopodial structures of the neuronal growth cones. Because growth cone collapse is associated with actin depolymerization, we considered whether small GTP-binding proteins of the rho subfamily might participate in collapsin-1 signal transduction. Recombinant rho, rac1, and cdc42 proteins were triturated into embryonic chick (DRG) neurons. Constitutively active rac1 increases the proportion of collapsed growth cones, and dominant negative rac1 inhibits collapsin-1-induced collapse of growth cones and collapsin-1 inhibition of neurite outgrowth. DRG neurons treated with dominant negative rac1 remain sensitive to myelin-induced growth cone collapse. Similar mutants of cdc42 do not alter growth cone structure, neurite elongation, or collapsin-1 sensitivity. Whereas the addition of activated rho has no effect, the inhibition of rho with Clostridium botulinum C3 transferase stimulates the outgrowth of DRG neurites. C3 transferase-treated growth cones exhibit little or no lamellipodial spreading and are minimally responsive to collapsin-1 and myelin. These data demonstrate a prominent role for rho and rac1 in modulating growth cone motility and indicate that rac1 may mediate collapsin-1 action.

Key words: collapsin-1; semaphorin; rac1; rho; growth cone collapse; neurite outgrowth; dorsal root ganglion neuron
Neuronal growth cones possess the sensory apparatus to distinguish among innumerable potential pathways and targets during nervous system development and regeneration (for review, see Strittmatter, 1995). Extracellular signals induce changes in the actin-based cytoskeleton of the growth cone and hence the morphology and motility of the growth cone. The molecular mechanisms by which extracellular clues are transduced to cytoskeletal rearrangements are defined poorly.

The semaphorin or collapsin family of proteins has been recognized as an important negative regulator of axonal outgrowth and terminal arborization (Kolodkin et al., 1992, 1993; Luo et al., 1993). Chick collapsin-1 induces growth cone collapse and a cessation of neurite outgrowth from at least a subset of DRG neurons (Raper and Kapf hammer, 1990; Luo et al., 1993). Insect semaphorins have a demonstrated in vivo role in axonal pathfinding and synaptic terminal branching (Kolodkin et al., 1992; Matthes et al., 1995). There are at least seven vertebrate semaphorins identified, and there may be as many as 20 members of this family (Inagaki et al., 1995; Luo et al., 1995; Messersmith et al., 1995; Puschel et al., 1995; Adams et al., 1996). A decrease in actin filaments after collapsin-1 application has been documented (Fan et al., 1993). The mechanisms by which collapsin-1 binding to an unidentified transmembrane receptor triggers this depolymerization are unclear.

In non-neuronal cells, the rho subfamily of monomeric rasrelated GTP-binding proteins has prominent effects on the actinbased cytoskeleton and on cell shape (Hall, 1990, 1994). In fibroblasts, rho activation has been linked to stress fiber formation and focal adhesions, rac1 activation has been linked to membrane

Received March 18, 1997; revised May 14, 1997; accepted May 23, 1997.

This work was supported by grants to S.M.S. from National Institutes of Health and from the Spinal Cord Research Fund of the Paralyzed Veterans of America. S.M.S. is a John Merck Scholar in the Biology of Developmental Disorders in Children. We thank A. Hall for the G-protein expression plasmids.

Correspondence should be addressed to Dr. Stephen M. Strittmatter, Departments of Neurology and Neurobiology, Yale University School of Medicine, P.O. Box 208018, New Haven, CT 06520.

Copyright (C) 1997 Society for Neuroscience $\quad 0270-6474 / 97 / 176256-08 \$ 05.00 / 0$ ruffling and lamellipodia, and cdc42 activation has been linked to filopodial formation (Nobes and Hall, 1995). Single amino acid substitutions have been identified that produce constitutively active or dominant negative forms of each of these proteins. The C3 transferase from Clostridium botulinum ADP ribosylates rho specifically and inactivates the G-protein.

The contribution of this class of G-proteins to the regulation of neuronal growth cone motility has come under investigation only recently. In neuroblastoma cells, the binding of lysophosphatidic acid (LPA) or thrombin binding to heterotrimeric G-proteincoupled receptors induces rapid neurite retraction (Jalink and Moolenaar, 1992; Jalink et al., 1994). The C3 transferase from $C$. botulinum has been shown to block the action of LPA, indicating that rho activation mediates the LPA regulation of neurite length in these cells (Jalink et al., 1994). A downstream target of activated rho has been identified as myosin light chain phosphorylase (Kimura et al., 1996), and an inhibitor of myosin light chain kinase, KT5926, also blocks LPA-induced neurite retraction (Jalink et al., 1994).

Further evidence for the involvement of rho-related small G-proteins in the regulation of neurite outgrowth comes from studies in which activated or dominant negative forms of these proteins are expressed in vivo. Alterations of rac1 activity, and to a lesser extent of cdc42 activity, lead to a failure in axonal extension from many neurons in the fly (Luo et al., 1994). Mice expressing constitutively active rac1 in cerebellar Purkinje cells exhibit alterations in dendritic morphology (Luo et al., 1996).

The present study was designed to examine the action of rho, rac1, and cdc42 activation or inhibition on the outgrowth and the sensitivity to collapsin-1 of chick DRGs. The data indicate that both rho and rac1 are capable of modulating chick DRG neurite outgrowth in culture and that rac1 activation may mediate the inhibitory effects of collapsin-1 on neurite outgrowth.

\section{MATERIALS AND METHODS}

Preparation of proteins: G-proteins, collapsin, and myelin. Monomeric human G-proteins and C. botulinum $\mathrm{C} 3$ transferase were produced in 
bacteria as glutathione $S$-transferase (GST) fusion proteins and then were treated with thrombin to remove the GST moiety (Nobes and Hall, 1995). Thrombin was removed from the samples by absorption to $p$-aminobenzamidine-agarose. The following derivatives were produced: wild-type rhoA (rho), a constitutively active form of rhoA with Gly at position 14 mutated to Val (V14rho), wild-type rac1 (rac), a constitutively active form of rac1 with Gly at position 12 mutated to Val (V12rac), a dominant negative form of rac1 with Thr at position 17 mutated to Asn (N17rac), wild-type cdc42 (cdc42), a constitutively active form of cdc42 with Gly at position 12 mutated to Val (V12cdc42), a dominant negative form of cdc 42 with Thr at position 17 mutated to Asn (N17cdc42), and the C3 exoenzyme from C. botulinum (C3). The rho and V14rho proteins contain a substitution at position 25 of Asn for Phe to enhance stability in Escherichia coli.

Collapsin-His ${ }_{6}$ was prepared as described (Goshima et al., 1995). Myelin fractions were prepared from bovine brain, and the proteins extracted with $2 \%$ octylglucoside were tested in growth cone collapse after the removal of detergent by dialysis (Igarashi et al., 1993).

$D R G$ culture conditions and trituration method. The preparation of chick E7 DRG explant and dissociated neuron cultures has been described previously (Strittmatter et al., 1994b; Goshima et al., 1995). For trituration experiments, neurons were suspended in $25 \mathrm{~mm}$ Tris- $\mathrm{HCl}, 150$ $\mathrm{mm} \mathrm{NaCl}, 5 \mathrm{~mm} \mathrm{MgCl}_{2}$, and $1 \mathrm{~mm}$ dithiothreitol, $\mathrm{pH}$ 7.5, with the rho subfamily proteins at $5 \mathrm{mg} / \mathrm{ml}$ or with $\mathrm{C} 3$ transferase at $0.1 \mathrm{mg} / \mathrm{ml}$; then the suspension was passed 50 times through a Gilson P200 pipette tip (Strittmatter et al., 1994b; Goshima et al., 1995). After trituration, neurons were plated in 25 volumes of F 12 medium with $10 \% \mathrm{FBS}$ and with $50 \mathrm{ng} / \mathrm{ml} 7 \mathrm{~S}-\mathrm{NGF}$ on a glass surface precoated sequentially with 100 $\mu \mathrm{g} / \mathrm{ml}$ poly-L-lysine and with $20 \mu \mathrm{g} / \mathrm{ml}$ laminin. For experiments with LPA, triturated neurons were transferred to serum-free medium (F-12 medium with $1 \%$ fatty acid-free BSA and with $50 \mathrm{ng} / \mathrm{ml} 7 \mathrm{~S}-\mathrm{NGF}$ ) for 3 $\mathrm{hr}$ before the growth cone collapse assay.

Neurite outgrowth and growth cone collapse. For outgrowth assays, triturated cells were plated for $1.5-2 \mathrm{hr}$, and then the agents to be tested were added to the medium. After an additional 2-3 hr of incubation, the cells were fixed, and total neurite length per neuron was measured for 75-150 cells (Strittmatter et al., 1994b; Goshima et al., 1995). The growth cone collapse assay for explant cultures has been described in detail (Raper and Kapf hammer, 1990; Strittmatter et al., 1994b; Goshima et al., 1995). For triturated cells, neurons were cultured for $4 \mathrm{hr}$ before test compounds were added for 20-30 min. The fraction of collapsed growth cones was scored as described for explant cultures.

Immunohistology. Dissociated chick E7 DRG neurons were cultured for $24 \mathrm{hr}$ and then were fixed for $30 \mathrm{~min}$ with ice-cold $4 \%$ paraformaldehyde and $20 \%$ sucrose in PBS. Samples then were incubated with 4 $\mu \mathrm{g} / \mathrm{ml}$ anti-rac1 mouse monoclonal antibody directed against human rac1 (Upstate Biotechnology, Lake Placid, NY). In some cases, rac1 protein at $1 \mathrm{mg} / \mathrm{ml}$ was added with the antibody to the incubation to demonstrate the specificity of the staining. Bound antibody was detected by the avidin-biotin complex method (Vector Laboratories, Burlingame, CA) with horseradish peroxidase enzyme and diaminobenzidine substrate as described (Goshima et al., 1995).

\section{RESULTS}

\section{Comparison of collapsin-1 action with LPA and thrombin action}

As a first step in assessing the role of small G-proteins in collapsin-1 action, we compared the effects of readily available pharmacological agents on collapsin- 1 action with their effects on LPA and thrombin action. The myosin light chain kinase inhibitor KT5926 blocks LPA-induced neurite retraction and also decreases the potency of recombinant collapsin-1 as a growth cone collapse factor (Fig. 1 $A$ ). A number of other agents had little or no effect on collapsin-1 action, including tyrosine kinase inhibitors, protein kinase $\mathrm{A}$ inhibitors, voltage-sensitive $\mathrm{Ca}^{2+}$ channel blockers, and depolarization with $\mathrm{KCl}$ (data not shown). The more general protein kinase inhibitor staurosporine and the protein kinase $\mathrm{C}$ activator phorbol 12-myristate 13-acetate both induced growth cone collapse at concentrations of $<10 \mathrm{~nm}$, but their action was not synergistic with collapsin-1 (data not shown).

The actions of LPA and thrombin are mediated by receptors
A

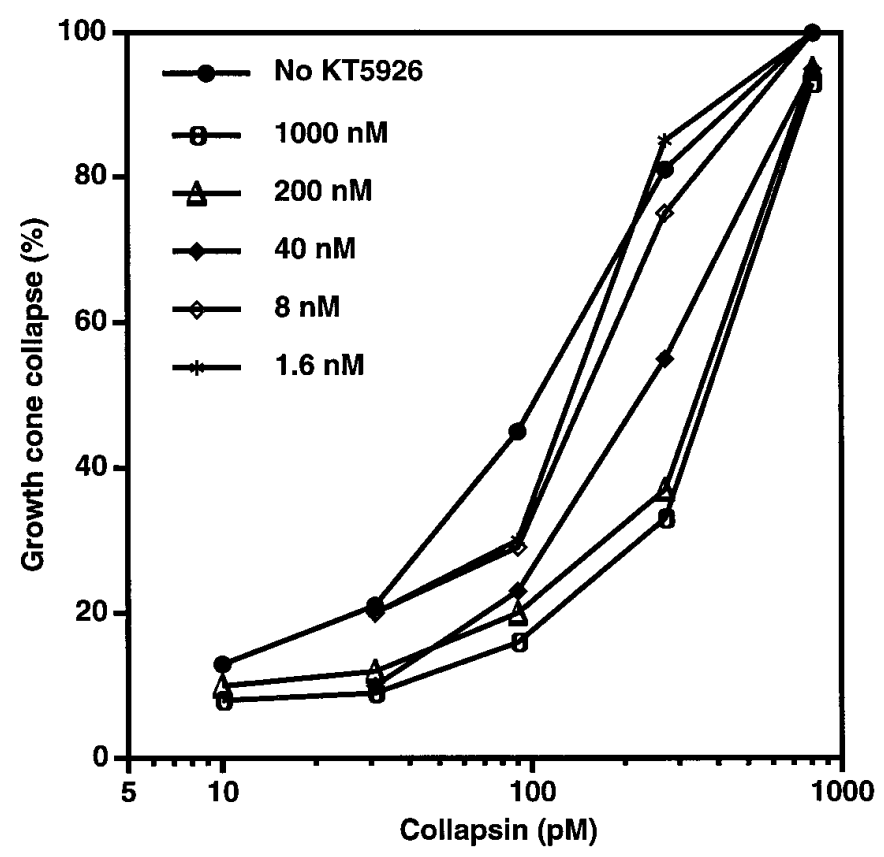

B

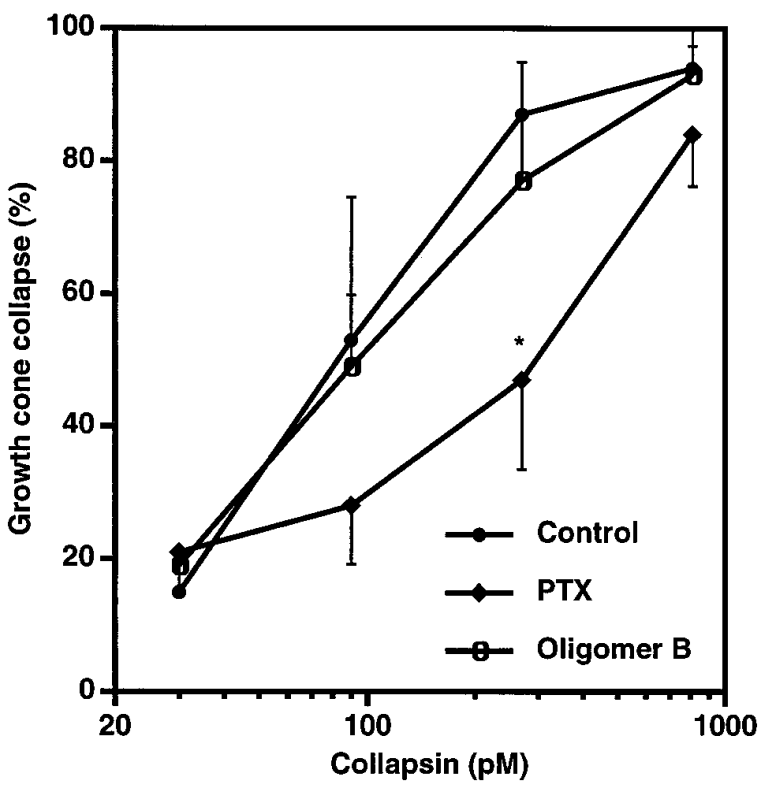

Figure 1. Collapsin-1-induced growth cone collapse is attenuated by KT5926 and PTX. $A$, Chick DRG explant cultures were preincubated for $2 \mathrm{hr}$ in culture medium with KT5926 at the indicated concentrations. Then growth cone collapse was assayed. Low concentrations of KT5926 shifted the collapsin-1 dose-response curve to the right by a factor of five. KT5926 had no direct effect on growth cone collapse in the absence of collapsin-1. The means from four to six separate experiments are shown. For each point, the SEM was $<10 \%$ of the value shown. $B$, Chick DRG explant cultures were preincubated for $3 \mathrm{hr}$ in growth medium with PTX (pertussis holotoxin) at $500 \mathrm{ng} / \mathrm{ml}$ or with the oligomer B subfraction of PTX at $500 \mathrm{ng} / \mathrm{ml}$. Then growth cone collapse was measured in the presence of the indicated concentrations of recombinant collapsin-His ${ }_{6}$. Whereas the oligomer B fraction had no effect, PTX decreased growth cone collapse at $200 \mathrm{pm}$ collapsin-1 significantly $(* p \leq 0.05$; Student's two-tailed $t$ test). The averages from five experiments \pm SEM are shown. 
linked to heterotrimeric G-proteins (Jalink et al., 1994). We considered whether recombinant collapsin-1 action also involves trimeric G-protein activation. Pertussis toxin (PTX) ADP ribosylates the $\alpha$ subunit of heterotrimeric G-proteins of the $\mathrm{G}_{\mathrm{o}}$ or $\mathrm{G}_{\mathrm{i}}$ class and blocks their activation by receptors. Growth cone collapse by crude whole brain membrane extracts (BMEs), which contain collapsin-1, is blocked by PTX (Igarashi et al., 1993), but this is because of the cell surface binding properties of PTX rather than the modification of G-proteins by PTX (Kindt and Lander, 1995). The isolated oligomer B fraction of PTX contains the cell surface binding domain but does not block purified recombinant collapsin-1-induced growth cone collapse (Fig. 1B). Thus, the decrease in collapsin- 1 potency by intact PTX suggests that collapsin-1 action involves heterotrimeric G-protein action, strengthening the similarity with LPA and thrombin action. The failure of PTX to block at higher collapsin-1 concentrations may be attributable either to PTX-insensitive G-proteins or to nonG-protein-dependent mechanisms. Oligomer B blockade of BME action may reflect the inhibition of collapsing agents other than collapsin-1 in the crude extract.

\section{Basal outgrowth in DRG neurons containing exogenous rho subfamily proteins}

To modulate the activity of rho subfamily G-proteins in DRG neurons, purified recombinant proteins were triturated with isolated neurons. Neurons were plated immediately after trituration; neurite extension and growth cone morphology were observed 2-5 hr later (Fig. 2). All of the triturated proteins were $>95 \%$ pure (Fig. $2 A$ ). Four hours after plating, the neurons triturated with buffer are indistinguishable from cells that have not been triturated. None of the recombinant proteins affect the number of neurons that attach to the laminin-coated surface under these conditions. Of the proteins altering rho activity, only $\mathrm{C} 3$ transferase alters outgrowth. Neurite extension doubles after C3 transferase treatment (Fig. 2D), and nearly all of the growth cones exhibit greatly reduced lamellipodial spreading (Fig. 2B,C). These data raise the possibility that under basal conditions a significant fraction of rho is likely to be activated. Of the rac1 proteins, the constitutively active form increases the percentage of growth cones with a collapsed appearance (Fig. 2B,C), and there is a slight trend toward decreased neurite extension that does not reach statistical significance (Fig. 2D). The weak V12rac effects mimic the action of collapsin- 1 . The cdc42 proteins at the same concentration do not alter growth cone appearance or neurite extension.

\section{Collapsin-1 sensitivity in DRG neurons containing rho subfamily proteins}

Neurons triturated with rho family members were exposed to collapsin-1, and then growth cone morphology and neurite extension were examined. In control cultures, exposure to collapsin-1 for $20 \mathrm{~min}$ increases the percentage of collapsed growth cones from 15 to $70 \%$ (Fig. $2 B, C$ ). Exposure to collapsin-1 during the interval from 2 to $5 \mathrm{hr}$ after plating decreases the extent of outgrowth by $50 \%$ (Fig. 2D). Collapsin-1-induced changes in growth cone collapse and in neurite outgrowth are attenuated markedly in neurons treated with dominant negative N17rac (Fig. $2 B-D)$. In contrast, constitutively active V12rac-treated and wildtype rac-treated cells exhibit essentially normal responsiveness to collapsin-1. Trituration with cdc42 proteins or buffer does not alter collapsin-1 sensitivity. Similarly, wild-type and activated rho do not alter collapsin-1 action. However, the C3 transferase- treated neurons displaying increased neurite outgrowth are minimally sensitive to the inhibitory effects of collapsin-1 (Fig. 2D). The decreased lamellipodial morphology of growth cones in C3 transferase-treated cultures is only slightly enhanced by collapsin-1 (Fig. 2B,C).

\section{Characterization of rac1 effects in DRG neurons}

The effect of dominant negative N17rac trituration is dependent on the dose of rac1 protein present during the trituration; concentrations in excess of $1 \mathrm{mg}$ of protein $/ \mathrm{ml}$ are required to achieve $>50 \%$ inhibition of collapsin-1-induced growth cone collapse (Fig. $3 A$ ). The specificity of N17rac action for endogenous rac1 pathways is suggested by the inactivity of dominant negative N17cdc42 (Fig. 2B,D). Furthermore, the cotrituration of constitutively active V12rac, but not constitutively active V14rho or V12cdc42, reverses partially the N17rac inhibition of collapsin-1induced growth cone collapse (Fig. 3B).

After trituration with dominant negative N17rac, the collapsin-1 dose-response curve for DRG growth cone collapse is shifted to the right by a factor of $15\left(\mathrm{EC}_{50}\right.$ from $60 \mathrm{pm}$ to $2 \mathrm{nM}$, Fig. $3 C$ ). The residual weak effect of collapsin-1 as a growth cone collapse factor in N17rac-triturated cells may be caused by an incomplete rac1 blockade achieved by the trituration method or by nonrac1 dependent collapsin-1-induced growth cone collapse mechanisms. As described above, trituration with constitutively active V12rac induces collapse of $20 \%$ of the growth cones (Fig. $2 B)$. The dose-response curve for collapsin-1-induced growth cone collapse is shifted to the left by a factor of two after trituration with constitutively active $\mathrm{V} 12 \mathrm{rac}\left(\mathrm{EC}_{50}\right.$ from 60 to 30 pM, Fig. 3C).

If rac1 is an endogenous modulator of collapsin-1-induced growth cone collapse, it must be present in the growth cone. Histological staining for rac1 demonstrates that the protein is found in growth cones and is present in filopodial structures at the very tip of the growth cone (Fig. 3D). Thus, the protein is in a position to mediate collapsin-1 action.

\section{C3 transferase action in DRG neurons}

The ability of the C3 exoenzyme to ADP-ribosylate specifically rho in mammalian cells, including neuroblastoma cells, has been demonstrated previously (Jalink et al., 1994). The action of C3 transferase in DRG neurons depends on the dose of C3 exoenzyme present during the trituration, with as little as $1 \mu \mathrm{g} / \mathrm{ml}$ causing $>50 \%$ of the DRG growth cones to collapse (Fig. $4 A$ ). Although constitutively active V14rho does not alter basal growth cone collapse or outgrowth (Fig. $2 B, D$ ), trituration with this protein reverses the $\mathrm{C} 3$ transferase effects on growth cone collapse and outgrowth (Fig. 4B,C). Neither constitutively active V12rac nor V12cdc42 reverses C3 transferase action. Taken together, these data support the specificity of C3 transferase for rho inhibition after trituration into DRG neurons.

\section{Dominant negative rac1 does not block the effects of rho inactivation}

The decrease in growth cone area caused by C3 transferase treatment is associated with increased neurite extension, whereas that caused by collapsin- 1 is associated with decreased extension. We considered whether dominant negative rac1 could block the effects of rho inhibition by $\mathrm{C} 3$ transferase as it blocks collapsin-1 action. When C3 transferase and N17rac are cotriturated, DRG neurites resemble C3 transferase-triturated neurites (Fig. 5). Thus, modulation of neurite extension by rho is not mediated primarily through rac1. Rho may act in separate pathway(s) 

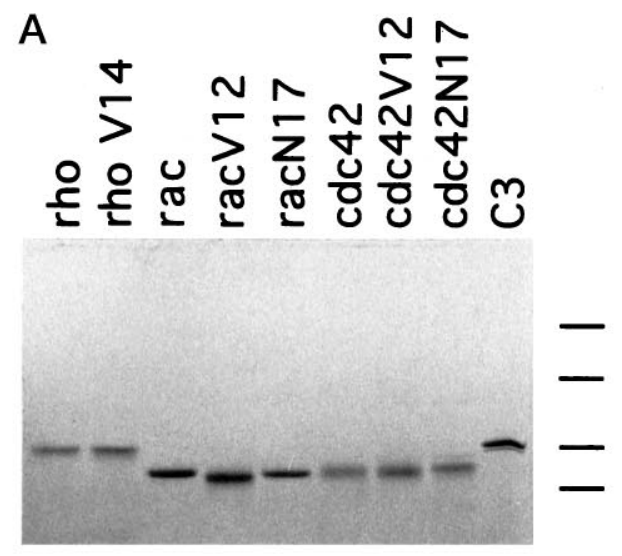

C

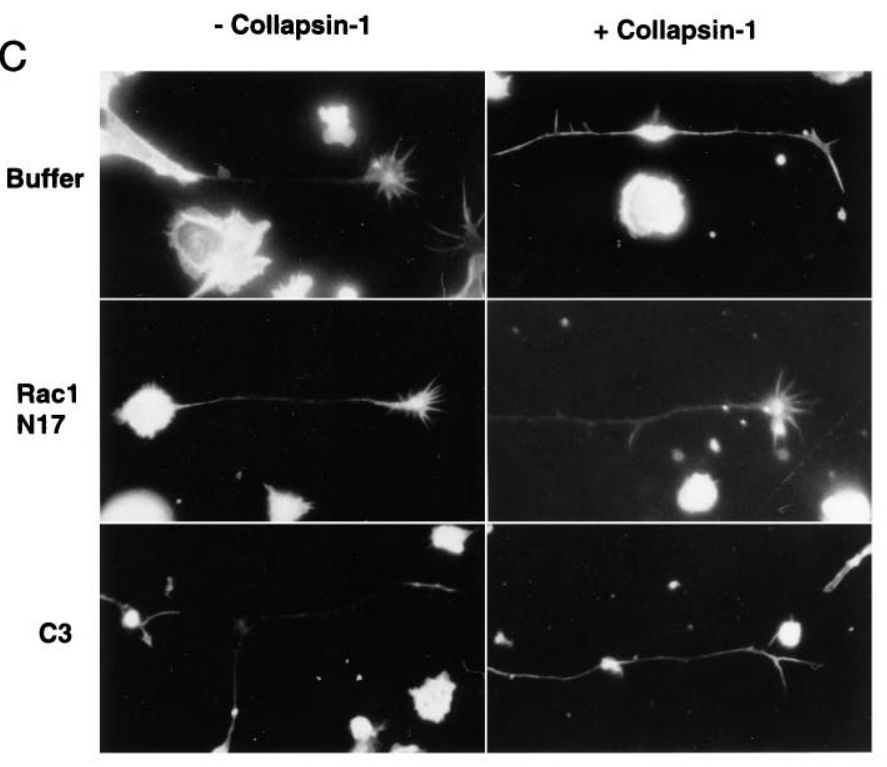

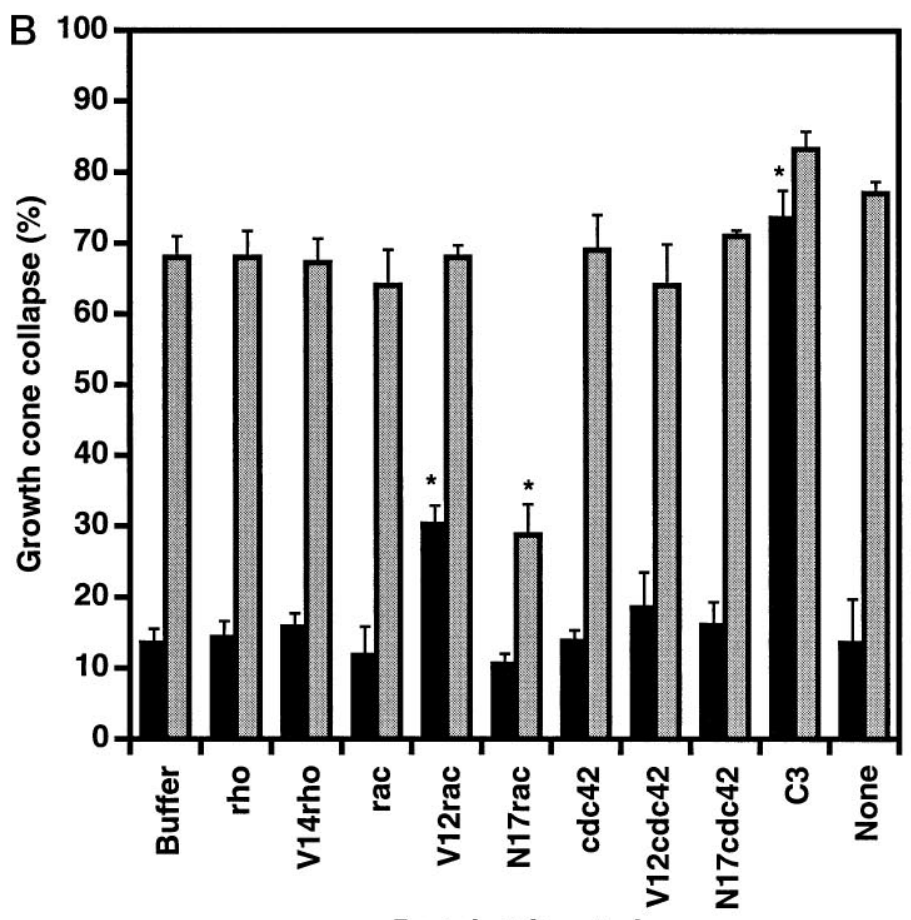

Protein triturated

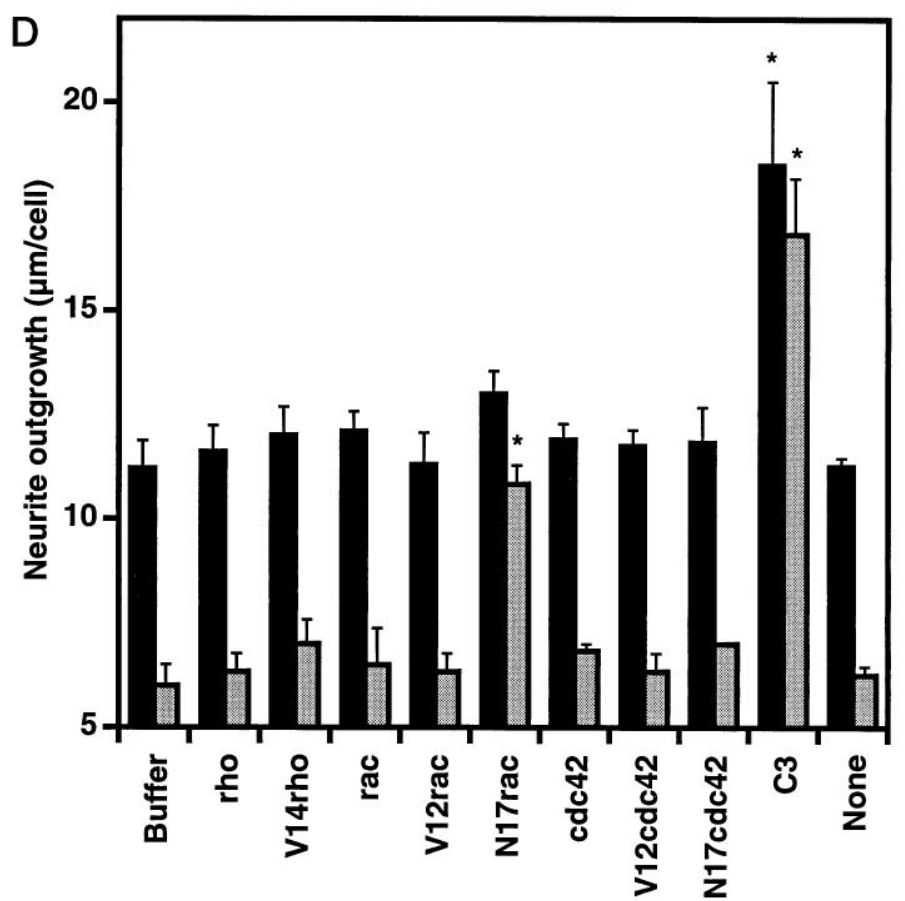

Protein triturated

Figure 2. Growth cone collapse and neurite outgrowth in DRG neurons triturated with the rho subfamily proteins. $A$, The protein preparations used for trituration were separated by SDS-PAGE and were stained with Coomassie blue. The migration of 45, 36, 25, and $21 \mathrm{kDa} M_{\mathrm{r}}$ standards is shown on the right. $B$, DRG neurons were triturated with the indicated proteins at $5 \mathrm{mg} / \mathrm{ml}$ for the rho family proteins and at $0.1 \mathrm{mg} / \mathrm{ml} \mathrm{for} \mathrm{C3} \mathrm{transferase.} \mathrm{After}$ $4 \mathrm{hr}$ of culture, growth cone collapse was assessed with (gray bars) or without (solid bars) a 20 min exposure to 200 pM collapsin-His ${ }_{6}$. The data are averages \pm SEM for three to nine separate experiments. The values marked with an asterisk are significantly different ( $p \leq 0.05$; Student's two-tailed $t$ test) from the values for buffer-triturated cells under the same conditions. $C$, DRG neurons were triturated with the indicated proteins and were exposed to collapsin- $\mathrm{His}_{6}$ as described in $B$. Actin was visualized by staining formalin-fixed cells with rhodamine-phalloidin. Magnification, $500 \times$. $D$, DRG neurons were triturated with the indicated proteins at $5 \mathrm{mg} / \mathrm{ml}$ for the rho family proteins and at $0.1 \mathrm{mg} / \mathrm{ml}$ for C3 transferase. After 2 hr of culture, neurons were exposed to 0 (solid bars) or $200 \mathrm{pm}$ ( gray bars) collapsin-His ${ }_{6}$ for an additional $3 \mathrm{hr}$, and then the average total neurite outgrowth per cell was determined (Goshima et al., 1995). The data are averages \pm SEM for three to nine separate experiments. The values marked with an asterisk are significantly different ( $p \leq 0.05$; Student's two-tailed $t$ test) from the values for buffer-triturated cells under the same conditions. 
Figure 3. Rac1 in collapsin-1 regulation of growth cone motility. $A-C$, DRG neurons were triturated with buffer or with various concentrations of the indicated G-proteins. Growth cone collapse with or without a $20 \mathrm{~min}$ exposure to

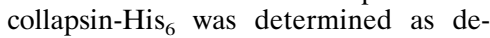
scribed in Figure 2. The data are averages \pm SEM for two to four separate experiments. $A$, Growth cone collapse after trituration of DRG neurons with various concentrations of N17rac protein was determined with $(\bigcirc)$ or without (๑) exposure to $200 \mathrm{pM}$ collapsin-His . $_{6}$. $B$, Growth cone collapse after trituration of DRG neurons with N17rac at 0 or 2.5 $\mathrm{mg} / \mathrm{ml}$ and with the indicated constitutively active G-proteins at 0 or $5 \mathrm{mg} / \mathrm{ml}$ was determined in the absence (solid bars) or in the presence (gray bars) of 200 pM collapsin-His ${ }_{6}$. Note that V12rac partially reverses the N17rac inhibition of collapsin-1-induced growth cone collapse. $C$, Growth cone collapse after trituration with buffer, with constitutively active V12rac, or with dominant negative N17rac was determined for DRG neurons exposed to the indicated concentrations of collapsin-His ${ }_{6} . D, D R G$ neurons were stained with $4 \mu \mathrm{g} / \mathrm{ml}$ monoclonal anti-rac1 antibody as described in Materials and Methods. Note the staining of rac1 in growth cone structures (top, bright-field). The addition of 1 $\mathrm{mg} / \mathrm{ml}$ recombinant rac1 protein to the primary antibody solution abolished all staining (bottom, bright-field). The bottom region contains three growth cones detectable by differential interference contrast observation (data not shown). Scale bar, $25 \mu \mathrm{m}$.
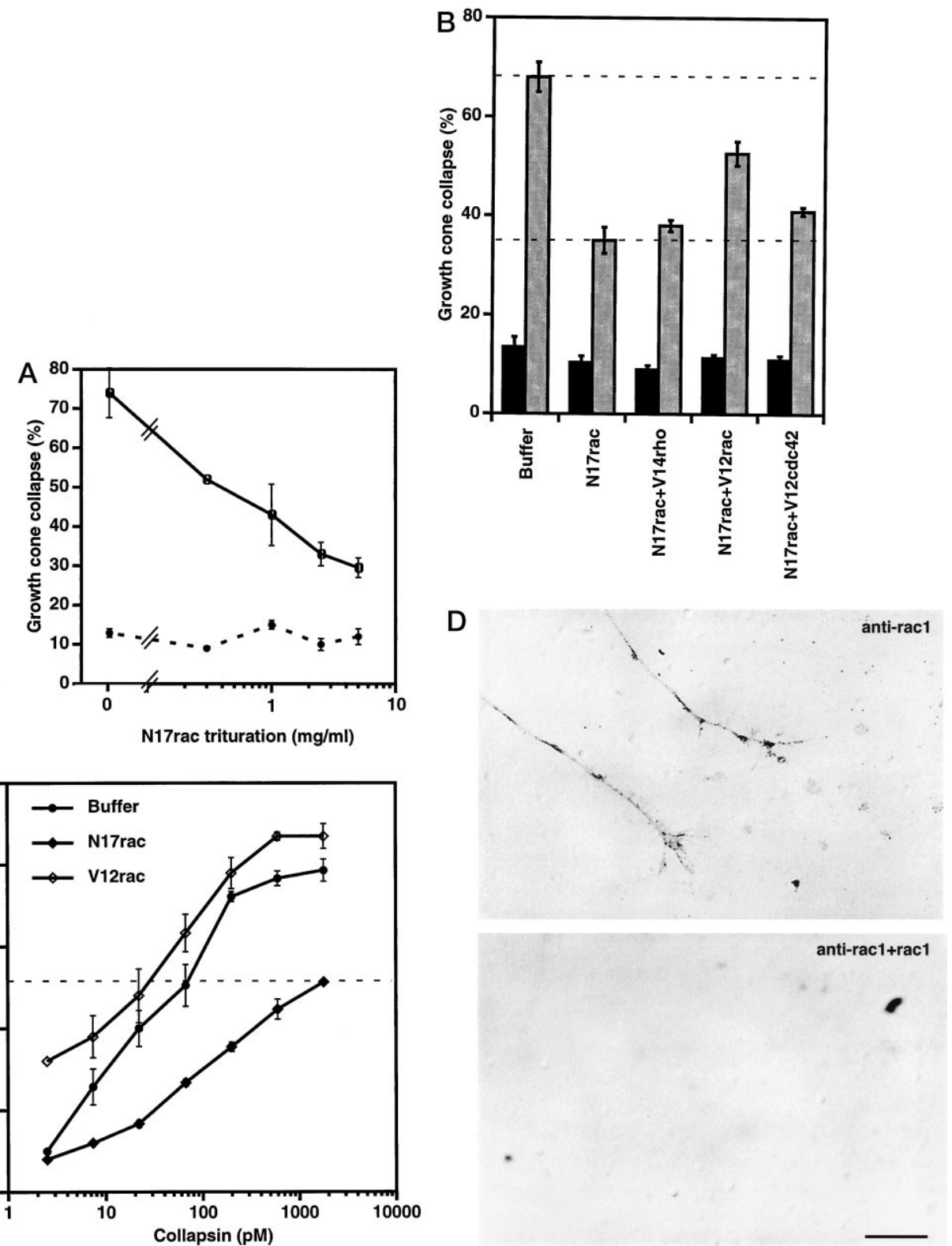

and/or function downstream of rac1 to regulate growth cone morphology and neurite extension.

\section{Inhibitory effects of myelin are not mediated by rho family members}

Components of CNS myelin have inhibitory influences on neurite regeneration and alter cultured DRG neuron morphology in a manner similar to that of collapsin-1 (Bandtlow et al., 1993). Growth cone collapse after exposure to CNS myelin extract is not altered by trituration with N17rac (Fig. $6 A, B$ ). This indicates that the $\mathrm{Ca}^{2+}{ }_{\mathrm{i}}$ dependent pathway used by inhibitory components of myelin (Bandtlow et al., 1993) is distinct from the rac1 dependent pathway used by collapsin-1. The rapidly growing, small growth cones present in $\mathrm{C} 3$ transferase-treated cultures are insensitive to myelin (Fig. 6A,B). LPA induces collapse of a small fraction of the DRG growth cones (Fig. $6 C$ ). This fraction is not altered by N17rac, implying that LPA-induced collapse proceeds via a different pathway than collapsin-1-induced collapse.

\section{DISCUSSION}

\section{Rac1 mediates collapsin-1 action}

Several lines of data from this study support the hypothesis that rac1 mediates collapsin-1 action in DRG neurons. Trituration of dominant negative N17rac nearly abolishes growth cone collapse by collapsin- 1 and greatly reduces neurite outgrowth inhibition by collapsin-1. Other rho subfamily members do not have these effects. The presence of rac1 in the growth cone is consistent with a role for this protein in collapsin-1 signaling. Constitutively active V12rac weakly mimics collapsin-1 action. The small magnitude of V12rac action may be caused by (1) the contribution of nonrac1 dependent mechanisms in collapsin-1-induced collapse, (2) the inefficiency of the trituration method, or (3) desensitizing mechanisms occurring during the 3-5 hr after trituration. Although collapsin-1 action is inhibited by N17rac, the effects of other extracellular proteins that induce the same morphological changes are not blocked by trituration with N17rac. This indicates 
A

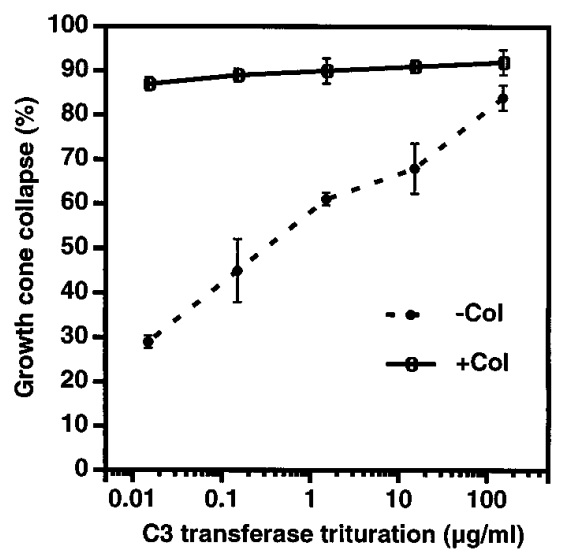

B

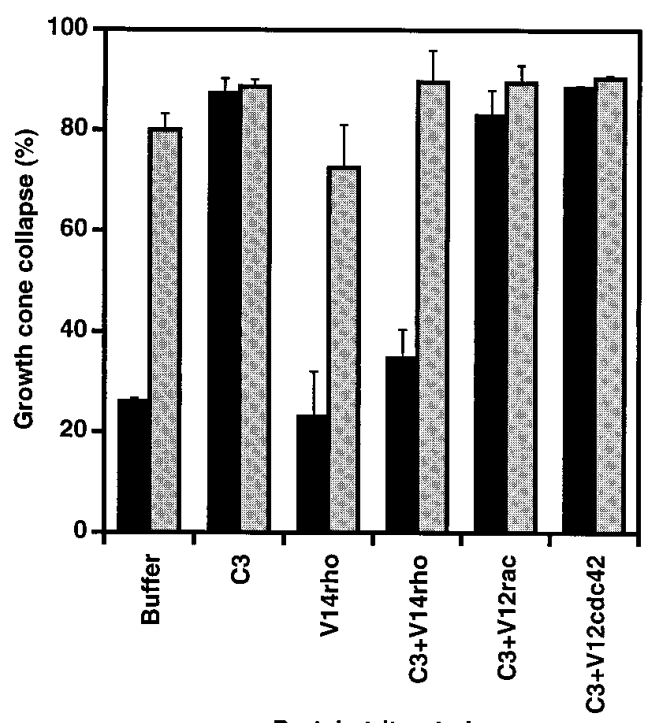

Protein triturated
C

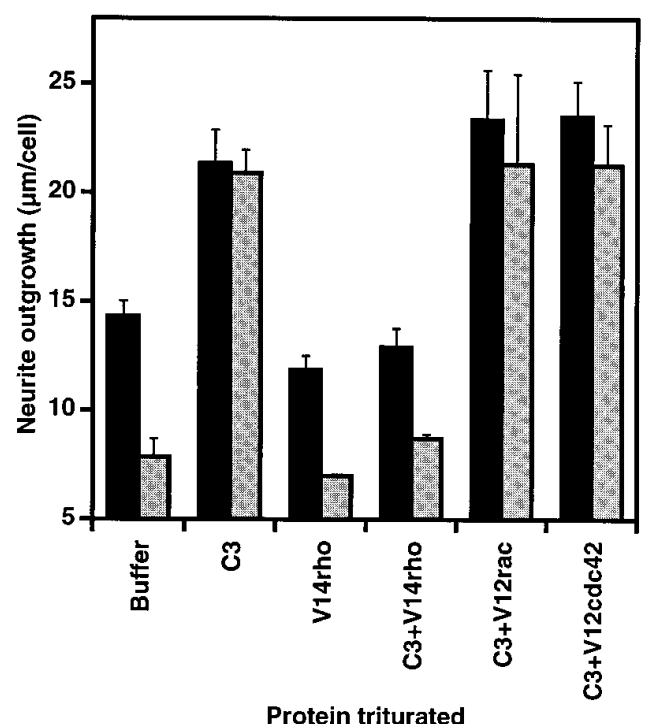

Protein triturated
Figure 4. C3 transferase action in DRG neurons. DRG neurons were triturated, cultured, and assayed as described in Figure 2. The data are averages \pm SEM for two to four separate experiments. $A$, Growth cone collapse after the indicated concentrations of C3 transferase were present during the trituration of DRG neurons was determined in the presence and absence of $200 \mathrm{pm}$ collapsin-His ${ }_{6}(\mathrm{Col}) . \mathrm{B}$, Growth cone collapse was determined after the trituration of DRG neurons with buffer, $4 \mu \mathrm{g} / \mathrm{ml} \mathrm{C} 3$ transferase, $5 \mathrm{mg} / \mathrm{ml}$ V14rho, or both proteins and after a subsequent exposure of the neurons to 0 (gray bars) or 200 pM (solid bars)

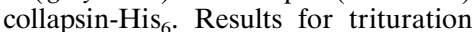
with both $\mathrm{C} 3$ transferase and either V12rac or V12cdc42 are also given. C, Average total neurite outgrowth per cell for neurons triturated as described in $B$ was determined after plating with ( gray bars) or without (solid bars) 200 pM collapsin- $\mathrm{His}_{6}$.
A

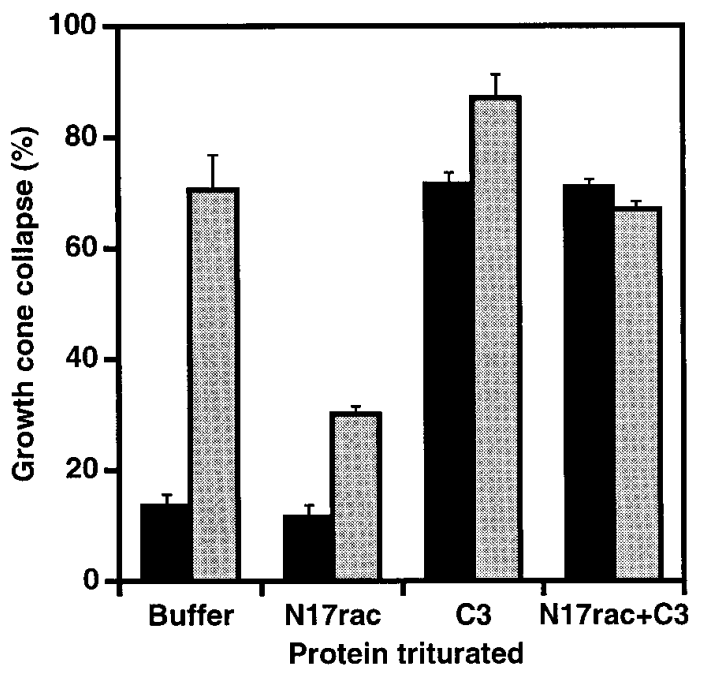

B

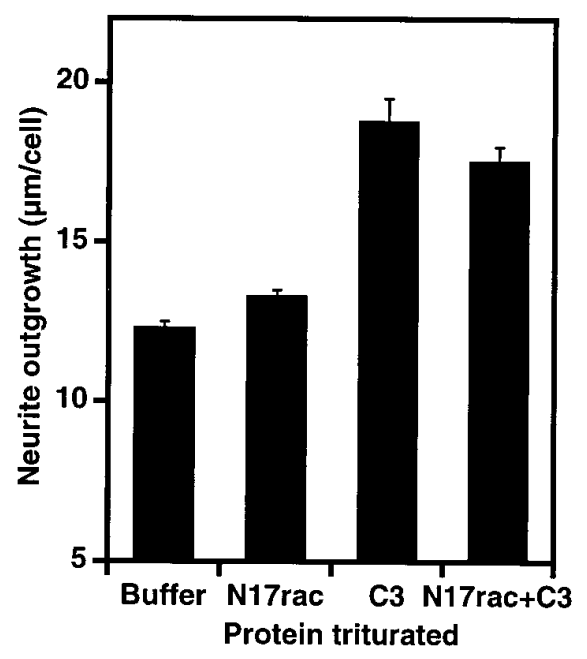

Figure 5. The effects of C3 transferase are not blocked by N17rac. DRG neurons were triturated with buffer, $5 \mathrm{mg} / \mathrm{ml}$ N17rac, $0.1 \mathrm{mg} / \mathrm{ml} \mathrm{C3}$ transferase, or both proteins. The data are averages \pm SEM for three to five separate experiments. $A$, Neurons were cultured for $4 \mathrm{hr}$ with the indicated proteins, and then growth cone collapse was assessed with (gray bars) or without (solid bars) a 20 min exposure to $200 \mathrm{pm}$ collapsin-His 6 . $B$, Average total neurite outgrowth per cell for neurons triturated with the indicated proteins was determined $4 \mathrm{hr}$ after plating. 
A

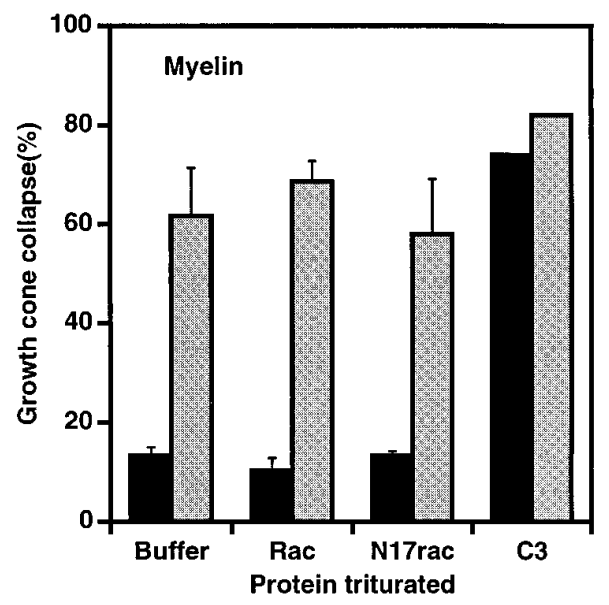

B

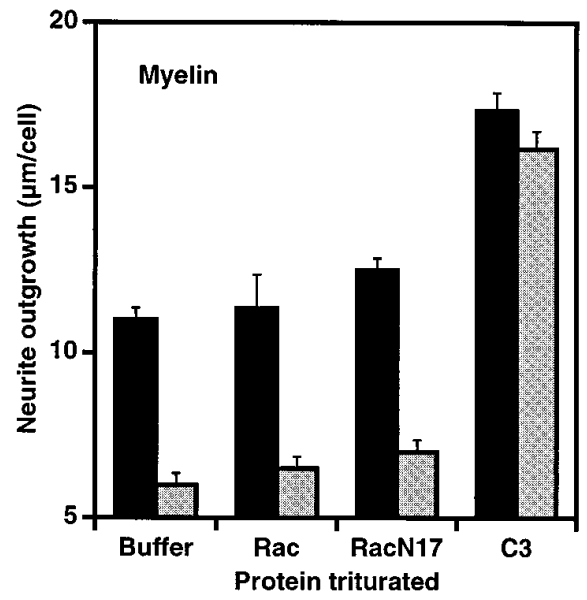

C

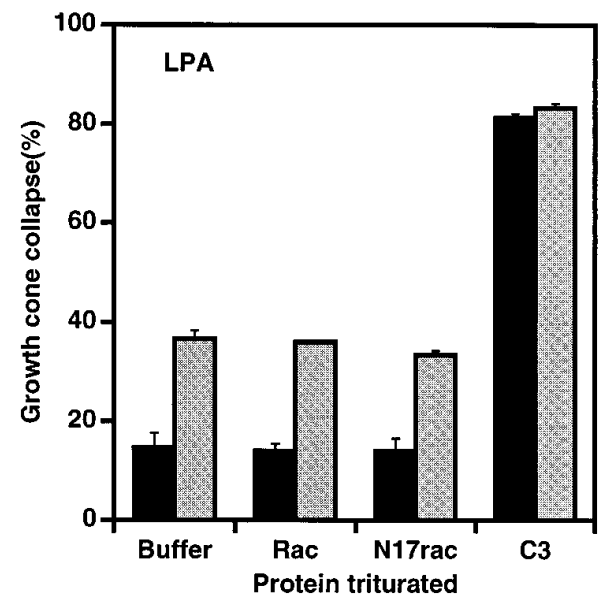

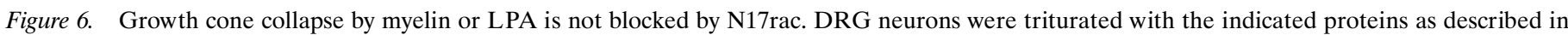

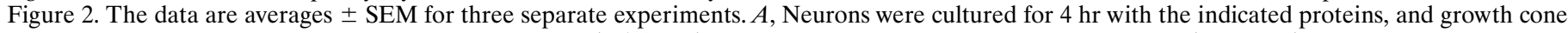

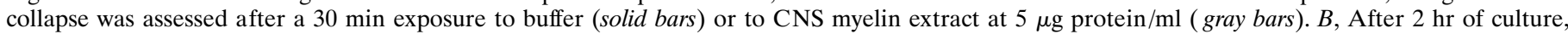

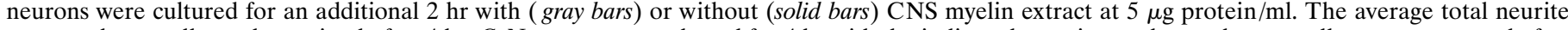

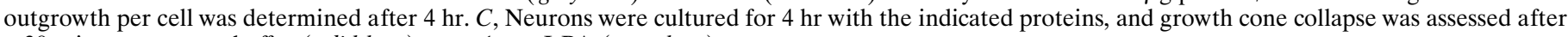
a 30 min exposure to buffer (solid bars) or to $1 \mu \mathrm{M} \mathrm{LPA} \mathrm{(gray} \mathrm{bars).}$

that rac1 is specifically involved in collapsin- 1 action and that the $\mathrm{Ca}^{2+}$-mediated growth cone collapse induced by components of CNS myelin does not use this monomeric G-protein.

Rho regulates neurite outgrowth, but the effects of rho are not altered by collapsin-1

The inhibition of rho with C3 transferase also alters the morphology of DRG neurons. This implies a significant level of rho activation in DRG growth cones under basal conditions. Furthermore, the data suggest that rho activation may decrease outgrowth but leads to greater growth cone spreading. In DRG neurons treated with a low dose of C3 transferase to reduce rho activity, constitutively active V14rho does increase growth cone spreading and decrease neurite outgrowth. The decreased growth cone spreading and increased outgrowth rate of rho-inhibited neurons are modulated only minimally by collapsin-1. These effects distinguish rho action from rac1 activation and collapsin-1 addition. Although it seems that rho exerts effects different from those exerted by rac1 and collapsin-1, growth cone morphology and motility may reflect additive rho and rac1 regulation. While rho activation is downstream of rac1 activation in $3 \mathrm{~T} 3$ fibroblasts (Nobes and Hall, 1995), this does not seem to be the case in DRG growth cones. Rho does not seem to be the primary mediator of collapsin-1 effects, but it may be a target for other DRG growth cone regulators, as suggested for LPA and thrombin (Jalink et al., 1994). The myosin light chain kinase inhibitor KT5926 may counteract myosin light chain phosphorylase regulation by rho (Kimura et al., 1996). In so doing, KT5926 partially reproduces the C3 transferase effect and decreases collapsin-1 sensitivity.

\section{Correlation of rho and rac1 activation with three states of DRG growth cone motility}

The present study identifies three alternative states for DRG growth cones in culture (Fig. 7). Under basal conditions, growth cones spread and advance at a moderate rate. Collapsin-1 decreases outgrowth rates and collapses growth cone lamellipodia and filopodia. Collapsin-1-induced alterations in growth cone behavior may be mediated by rac1 activation and are blunted by the presence of dominant negative N17rac. In contrast, the inhi-

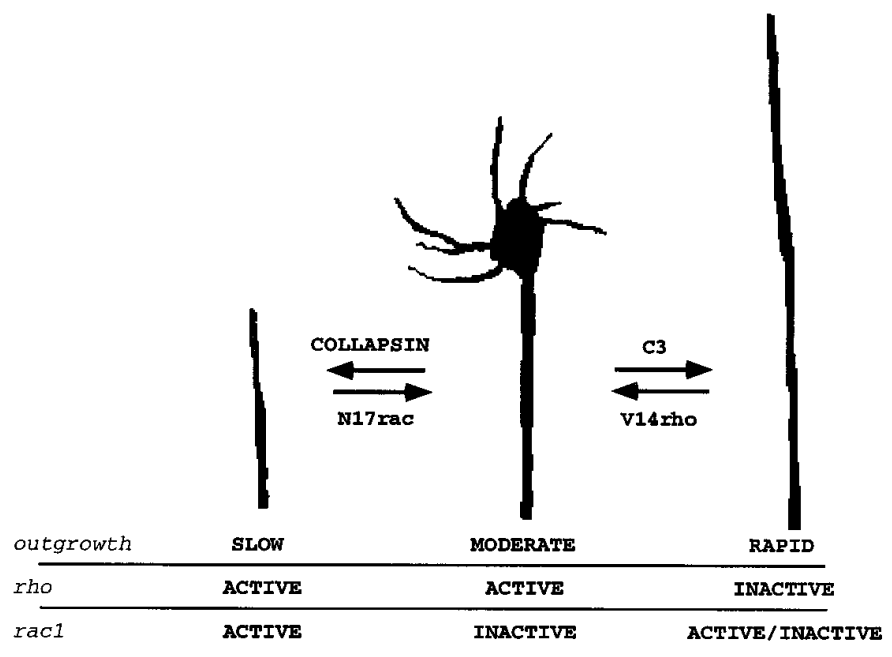

Figure 7. Model for rho and rac1 regulation of DRG growth cone function. Three states for DRG growth cones are classified by morphological appearance, neurite outgrowth rate, rho activation state, and rac1 activation. See Discussion for details.

bition of rho function by $\mathrm{C} 3$ transferase increases outgrowth rate and decreases growth cone area. The basal state seems to be correlated with rho activation and rac1 inactivity. Confirmation of this model will require methods to monitor the activation state of both rac1 and rho within DRG growth cones.

\section{Mechanism of rac1 activation: dbl proteins, G-protein cascade, and CRMP}

The mechanism by which rac1 in neurons might be activated by extracellular collapsin-1 is unclear. In other cell types, proteins with domains homologous to the human dbl protein act upstream of rac1 as guanine nucleotide exchange factors (Boguski and McCormick, 1993), but the presence of these proteins in neuronal growth cones has not been studied. Receptors of several classes seem to be capable of activating rac1 in other cells, including receptor tyrosine kinases, serpentine receptors coupled to het- 
erotrimeric G-proteins, and cytokine receptors of the tumor necrosis factor class. A central role for heterotrimeric G-proteins in growth cone signal transduction is supported by a number of studies (Strittmatter et al., 1990, 1993, 1994a, 1995). Data presented here indicate that heterotrimeric G-proteins (Fig. 1B) may be involved in collapsin-1 signaling. We have identified an intracellular family of neuronal proteins, CRMPs, that are required for collapsin action, but their interaction with other members of this signaling pathway is not established (Goshima et al., 1995; Wang and Strittmatter, 1996). There are no data indicating that intracellular $\mathrm{Ca}^{2+}$ levels are likely to mediate collapsin action. Identification of a collapsin-binding receptor will facilitate greatly further delineation of this pathway.

\section{Rac1 effectors in DRG neurons}

Rac1 is capable of reorganizing the actin-based cytoskeleton in non-neuronal cells and of activating a number of protein kinases (Hall, 1994; Coso et al., 1995; Minden et al., 1995; Nobes and Hall, 1995). Collapsin-1-induced changes in cell shape may be mediated by protein kinases such as PAK (Manser et al., 1994). After activation by rac1, such kinases are hypothesized to modulate cytoskeletal function. The recent advances in the understanding of the effects of rho on non-neuronal cell shape (Kimura et al., 1996) predict that similar experiments will be feasible for rac1 in developing neurons.

\section{REFERENCES}

Adams RH, Betz H, Puschel AW (1996) A novel class of murine semaphorins with homology to thrombospondin is differentially expressed during early embryogenesis. Mech Dev 57:33-45.

Bandtlow CE, Schimdt MF, Hassinger TD, Schwab ME, Kater SB (1993) Role of intracellular calcium in NI-35-evoked collapse of neuronla growth cones. Science 259:80-83.

Boguski MS, McCormick F (1993) Proteins regulating Ras and its relatives. Nature 366:643-654.

Coso OA, Chiariello M, Yu JC, Teramoto H, Crespo P, Xu N, Miki T, Gutkind JS (1995) The small GTP-binding proteins rac1 and cdc42 regulate the activity of the JNK/SAPK signaling pathway. Cell 81:1137-1146.

Fan J, Mansfield SG, Redmond T, Gordon-Weeks PR, Raper JA (1993) The organization of F-actin and microtubules in growth cones exposed to a brain-derived collapsing factor. J Cell Biol 121:867-878.

Goshima Y, Nakamura F, Strittmatter P, Strittmatter SM (1995) Collapsin-induced growth cone collapse mediated by an intracellular protein related to UNC-33. Nature 376:509-514.

Hall A (1990) The cellular functions of small GTP-binding proteins. Science 249:635-640.

Hall A (1994) Small GTP-binding proteins and the regulation of the actin cytoskeleton. Annu Rev Cell Biol 10:31-54.

Igarashi M, Strittmatter SM, Vartanian T, Fishman MC (1993) G Protein mediation of signals that cause growth cone collapse. Science 259:77-79.

Inagaki S, Furuyama T, Iwahashi Y (1995) Identification of a member of the mouse semaphorin family. FEBS Lett 370:269-272.

Jalink K, Moolenaar WH (1992) Thrombin receptor activation causes rapid neural cell rounding and neurite retraction independent of classic second messengers. J Cell Biol 118:411-419.

Jalink K, van Corven EJ, Hengeveld T, Morii N, Narumiya S, Moolenaar WH (1994) Inhibition of lysophosphatidate- and thrombin-induced neurite retraction and neuronal cell rounding by ADP ribosylation of the small GTP-binding protein rho. J Cell Biol 126:801-810.

Kimura K, Ito M, Amano M, Chicharo K, Fukata Y, Nakafuku M,
Yamamori B, Feng J, Naano T, Okawa K, Iwamatsu A, Kaibichi K (1996) Regulation of myosin phosphatase by rho and rho-associated kinase (rho-kinase). Science 273:245-248.

Kindt RM, Lander AD (1995) Pertussis toxin specifically inhibits growth cone guidance by a mechanism independent of direct $G$ protein inactivation. Neuron 15:79-88.

Kolodkin AL, Matthes DJ, O'Connor TP, Patel NH, Admon A, Bentley D, Goodman CS (1992) Fasciclin IV: sequence, expression, and function during growth cone guidance in the grasshopper embryo. Neuron 9:831-845.

Kolodkin AL, Matthes DJ, Goodman CS (1993) The semaphorin genes encode a family of transmembrane and secreted growth cone guidance molecules. Cell 75:1389-1399.

Luo L, Liao YJ, Jan LY, Jan YN (1994) Distinct morphogenetic functions of similar small GTPases: Drosophila drac1 is involved in axonal outgrowth and myoblast fusion. Genes Dev 8:1787-1802.

Luo L, Hensch TK, Ackerman L, Barbel S, Jan LY, Jan YN (1996) Differential effects of the rac1 GTPase on Purkinje cell axons and dendritic trunks and spines. Nature 379:837-840.

Luo Y, Raible D, Raper JA (1993) Collapsin: a protein in brain that induces the collapse and paralysis of neuronal growth cones. Cell 75:217-227.

Luo Y, Shepherd I, Li J, Renzi MJ, Chang S, Raper JA (1995) A family of molecules related to collapsin in the embryonic chick nervous system. Neuron 14:1131-1140.

Manser E, Leung T, Salihuddin H, Zhao Z, Lim L (1994) A brain serine-threonine protein kinase activated by $\operatorname{cdc} 42$ and rac1. Nature 367:40-46.

Matthes DJ, Sink H, Kolodkin AL, Goodman CS (1995) Semaphorin II can function as a selective inhibitor of specific synaptic arborizations. Cell 81:631-639.

Messersmith EK, Leonardo ED, Shatz CJ, Tessier-Lavigne M, Goodman CS, Kolodkin AL (1995) Semaphorin III can function as a selective chemorepellent to pattern projections in the spinal cord. Neuron 14:949-959.

Minden A, Lin A, Claret FX, Abo A, Karin M (1995) Selective activation of the JNK signaling cascade and c-Jun transcriptional activity by the small GTPases rac1 and cdc42Hs. Cell 81:1147-1157.

Nobes CD, Hall A (1995) Rho, rac1, and cdc42 GTPases regulate the assembly of multimolecular focal complexes associated with actin stress fibers, lamellipodia and filopodia. Cell 81:53-62.

Puschel AW, Adams RH, Betz H (1995) Murine semaphorin D/collapsin is a member of a diverse gene family and creates domains inhibitory for axonal extension. Neuron 14:941-948.

Raper JA, Kapfhammer P (1990) The enrichment of a neuronal growth cone collapsing activity from embryonic chick brain. Neuron 2:21-29.

Strittmatter SM (1995) Neuronal guidance molecules: inhibitory and soluble factors. Neuroscientist 1:255-258.

Strittmatter SM, Valenzuela D, Kennedy TE, Neer EJ, Fishman MC (1990) $G_{o}$ is a major growth cone protein subject to regulation by GAP-43. Nature 344:836-841.

Strittmatter SM, Cannon SC, Ross EM, Higashijima T, Fishman MC (1993) GAP-43 augments G protein-coupled receptor transduction in $X$. laevis oocytes. Proc Natl Acad Sci USA 90:5327-5331.

Strittmatter SM, Fishman MC, Zhu X-P (1994a) Activated mutants of the $\alpha$ subunit of $\mathrm{G}_{\mathrm{o}}$ promote an increased number of neurites per cell. J Neurosci 14:2327-2338.

Strittmatter SM, Igarashi M, Fishman MC (1994b) GAP-43 peptides modulate growth cone morphology and neurite outgrowth. J Neurosci 14:5501-5513.

Strittmatter SM, Frankhauser C, Huang PL, Mashimo H, Fishman MC (1995) Neuronal pathfinding is abnormal in mice lacking the neuronal growth cone protein GAP-43. Cell 80:445-452.

Wang LH, Strittmatter SM (1996) A family of rat CRMP genes is differentially expressed in the nervous system. J Neurosci 16:61976207. 